industry are apparent only in the export of yarn; but the mineral resources of the country were better exploited than in subsequent years, and the items broadcloth, blankets, and rugs show that the woollen manufacture, if small, was in a healthy and comparatively flourishing condition. Taliing the total of export trade we can well understand the annoyance of the industrial population at the misery entailed by the Rebellion. The process of recuperation began in 1655, and proceeded with such rapidity that in 1665 the country had more than recovered the ground lost during the war. But the conditions of trade were no longer what they had been. The woollen industry, for example, had suffered severely, and one branch of the trade, the manufacture of rugs, had practically disappeared. The country had relapsed into a more primitive condition, and the fact that more than one-fourth of the whole export trade of Ireland in 1665 was due to the export of oxen alone is significant of the direction trade was taking. The Act 18 and 19 Charles II, cap. 2, prohibiting the importation of live stock into England, put a sudden end to this state of affairs; but, as the figures for 1669 show, the Act was no real injury to Ireland, though it may have been, and in my opinion was to England. On the contrary the trade of Ireland was in a much healthier and more progressive state in 1669 than it was in $\mathbf{1 6 6 5 .}$

R. Dunlop.

\title{
Chatham and the Representation of the Colonies in the Imperial Parliament.
}

Chatham, the first statesman to make his countrymen realise the importance of their colonial empire, saw clearly that the troubles of his day with America would never be settled until the relation of responsibility to representation had been determined. In one of his earliest speeches on the subject he pointed out that it was unfair to call upon the American colonies to pay imperial taxes as long as they were unrepresented in parliament. Ultimately his proposal was that taxes should be granted by the colonies for imperial purposes through their congress; but he appears to have carefully considered the possibility of making the house of commons itself a federal assembly. Among his papers preserved at the Record Office are two schemes drawn up with that object. One of them contemplated the inclusion of Irish representatives ${ }^{1}$ the other ${ }^{2}$

' This plan is to be found in bundle 82 (marked 'Miscellaneous ') of the Chatham Papers. It is dated 1770 and signed 'Amor Patriae.' It proposes 50 MI.P.'s and 10 peers for the American and West Indian colonies, and 30 M.P.'s and 10 peers (to be elected) for Ireland.

2 This, the plan printed below, is to be found in bundle 97 of the Chatham Papers. The bundle is marked ' $N$. America ; Undated, and 1764-74.' The plan is unsigned and undated. 
and more elaborate plan is worth quoting in full, for, though in some obvious respects out of date, it contains suggestions and precautions as well worth attention now as a century and a quarter ago. That the scheme was Chatham's own in its details is not probable, but in its main outlines at any rate it coincides with his well-known riews for making the house of commons more truly representative.

Basil Williauss.

Scheme for the better uniting and cementing the mutual interest and peace of Great Britain and her Colonies by representation in the Parliament of Great Britain and Dominions thereto belonging, viz.
(1) $\left\{\begin{array}{l}\text { Massachusets } \\ \text { Pennsylvania }\end{array}\right.$
Virginia
(2) $\left\{\begin{array}{l}\text { Connecticut } \\ \text { New York } \\ \text { Jamaica }\end{array}\right.$
Each 4 members to represent them, or a smaller number at their option.
Each 3 members, but q. if Jamaica may Canada
Maryland
S. Carolina
(3) E. and V. Jerseys not expect to be in the 1st class.
Nova Scotia
New Hampshire
Rhode I.
Lower Counties of Penns.
N. Carolina
Georgia
E. Florida
(4)
W. Florida
Bahamas
Bermuda
Barbadoes
Antigua
St. Christopher
Nevis
Montserrat
Granados
Dominica
St. Vincent
Tobago
Each 2 members, but q. if Maryland and perbaps $\mathrm{S}$. Carolina may not request to be in the 2 nd class.
1 eacb, but q. if Rhode I., New Hamp- shire, Barbadoes, Antigua may not request to be included in the $3 \mathrm{rd}$ class.
N.B.-If any of the asscmblies of the smaller islands should think the expense of a sole representation by one member to each too heavy an expense, in such case two or more of such may join so they are near and convenient to each other, and to elect either jointly or by turns in rotation.

1st. These to be elected by each assembly from among themselres.

2nd. It will be needful to exempt them from the same qualifications which are the condition of British members enjoying a seat in parliament respecting the value of their real estates.

3rd. It may be needful to make a clause in the Act that on the dissolving any parliament the same members which represented America in such dissolved parliament should continue to represent them in the next ensuing until others are returned from their respective assemblies in lieu. 
4th. It may be needful that a special distance of time be allowed in the new writts for American members beyond the usual time in Great Brittain, perhaps six (or not exceeding twelve) months.

5th. The residence (in or near London) of every American member may be constantly required to be left in writing with the speaker of the house of commons.

6th. In order to prevent the evil effect of any mistrust of the colonists being liable to be overburthened with taxes beyond their reasonable abilities, it may be enacted that they shall not be liable to any other internal tax than a pound rate on their estates (unless the assembly of any colony should petition for another mode to them preferable), which pound rate or tax on their estates not to exceed threepence in times of peace nor one shilling in time of war, and on these conditions the mother country to protect and defend the whole, and that without further requisitions.

7th. It's not unliliely that the Americans may wish for some restrictions on their maritime and inland trade to be taken off in case of an union, and that may be considered afterwards.

8th. The Act of Navigation at all events should be preserved inviolate, and as the sixth article is in favour of the colonies, to secure their interest, it's but reasonable this should be added to secure the reasonable interest of the mother country. ${ }^{3}$

\section{Morit: Brosch.}

Dr. Monttz Brosch, who died at Venice on $14 \mathrm{July}$ last, in the 79th year of his age, was not only an eminent historian but a man of letters of no ordinary type. He won his spurs as a joumalist in Vienna so far back as the days of Schmerling, whose constitutional' policy, together with the foreign policy of Count Rechberg, found in Brosch, then a much-read writer in the Iranderer, one of its most resolute opponents. A German Bohemian by bfith and parentage, he through life resented a course of political action which in his judgment could only lead to the extrusion of Austria from Germany. Thus before very long his choice was made ; and more than a generation ago he definitively, but at the same time without the shadow of a promunciamiento, abandoned political writing for historical work. But his earlier training stood him in good stead in his later productions.

Already in 1873 he inscribed himself as a regular reader at the Archives of State in Venice, in which city most of the remainder of his life was spent. He seems at first to have intended to devote himself to the study of Spanish history in the age of Charles $V$; but ill health or other reasons induced him, in his earliest historical

\footnotetext{
3 It may be noted that the additional members of parliament would number either forty-five or fifty-two, according to the total finally decided in de abtul cases.
} 